\title{
Postępowanie w sprawach o naruszenie posiadania, czyli o konieczności ograniczenia ilości postępowań odrębnych w Kodeksie postępowania cywilnego. Wybrane zagadnienia
}

\author{
Proceeding in cases involving infringement of possession: the need for reduction \\ of numbers of specific types of proceedings in the Polish Civil Procedure Code. \\ Selected issues \\ Производство по делам о нарушении владения, то есть о необходимости \\ сокращения количества особых производств в Гражданско-процессуальном \\ кодексе. Избранные вопросы \\ AGNIESZKA GÓRA-BŁASZCZYKOWSKA \\ Dr hab., Akademia Sztuki Wojennej \\ e-mail: a.blaszczykowska@akademia.mil.pl, https://orcid.org/0000-0002-6862-3840
}

\begin{abstract}
Streszczenie: Podjęcie tematu wynika ze zwiększania liczby postępowań odrębnych w Kodeksie postępowania cywilnego, co powoduje odwrócenie istniejącej uprzednio i naturalnej proporcji między postępowaniem zwykłym, służącym rozpoznawaniu większości spraw, a postępowaniami odrębnymi, mającymi służyć wyłącznie rozpoznawaniu pewnych rodzajów spraw. Przepisy art. 478 i 479 K.p.c. budzą poważne wątpliwości w praktyce sądów, nie są adekwatne do potrzeb praktyki i nie są w pełni skorelowane z przepisami prawa materialnego. Dlatego postępowanie w sprawach o naruszenie posiadania nie wymaga, zdaniem autorki, odrębnej regulacji i powinno zostać usunięte z Kodeksu.
\end{abstract}

Słowa kluczowe: postępowanie cywilne, postępowania odrębne, postępowanie w sprawach o naruszenie posiadania, ochrona posiadania

Summary: The topic is necessitated by the increase in the number of separate proceedings in the Polish Civil Procedure Code, which reverses previously existing and natural proportion between ordinary proceedings, normally used to hear most cases, and separate proceedings, which are only to be used to hear certain types of cases. Provisions of Articles 478 and 479 of the Polish Civil Procedure Code raise serious doubts in the practice of courts and are inadequate to the needs of the practice. They are also not fully correlated with the provisions of substantive law (the Polish Civil Code). Therefore, according to the author, proceedings in cases of infringement of possession do not require a separate regulation and should be removed from the Polish Civil Procedure Code.

Key words: civil procedure, specific types of proceedings, proceeding in cases involving infringement of possession, protection of possession

Резюме: Рассмотрение данной темы обусловлено увеличением количества особых производств в Гражданско-процессуальном кодексе, что приводит к нарушению ранее существовавшей и естественной пропорции между обычным производством, служащим для рассмотрения большинства дел, и особым производством, предназначенным только для рассмотрения определенных видов дел. Положения статей 478 и 479 Гражданско-процессуального кодекса вызывают серьезные сомнения в практике судов, они не адекватны потребностям практики и не полностью соотносятся с положениями материального права. Поэтому, по мнению автора, производство по делам о нарушении владения не требует отдельного регулирования и должно быть исключено из Кодекса.

Ключевые слова: гражданское производство, особые производства, производство о нарушении владения, защита владения 


\section{Wstęp}

Asumptem do zajęcia się tematem jest systematyczne zwiększanie ilości postępowań odrębnych w Kodeksie postępowania cywilnego ${ }^{1}$, co pociąga za sobą odwrócenie istniejącej uprzednio i naturalnej proporcji między postępowaniem zwykłym, służącym rozpoznawaniu większości spraw, a postępowaniami odrębnymi, mającymi służyć tylko rozpoznawaniu pewnych rodzajów spraw².

Co znamienne, ilość postępowań odrębnych wzrasta: w ostatnim czasie oprócz postępowania w sprawach gospodarczych ${ }^{3}$ wprowadzono do Kodeksu również postępowanie w sprawach własności intelektualnej. Jednocześnie w Kodeksie (nadal) funkcjonują postępowania odrębne w sprawach niemających cywilnego charakteru, które powinny zostać przekazane do właściwości sądów administracyjnych ${ }^{5}$. Chodzi nie tylko o postulowane od dawna przekazanie spraw z zakresu ubezpieczeń społecznych do sądów administracyjnych ${ }^{6}$, ale także o przekazanie sądom administracyjnym spraw z odwołań od decyzji administracyjnych, wydanych przez

1 Ustawa z dnia 17 listopada 1964 r. - Kodeks postępowania cywilnego, tekst jednolity: Dz. U. z 2021 r. poz. 11 z późn. zm. (dalej: K.p.c.).

2 Tak trafnie I. Kunicki, w: W. Broniewicz, A. Marciniak, I. Kunicki, Postępowanie cywilne w zarysie, Warszawa 2016, s. 352.

3 W wyniku nowelizacji Kodeksu postępowania cywilnego, dokonanej w art. 1 pkt 156 ustawy z dnia 4 lipca 2019 r. o zmianie ustawy - Kodeks postępowania cywilnego oraz niektórych innych ustaw (Dz. U. z 2019 r. poz. 1469), w części pierwszej w Księdze pierwszej w Tytule VII, po Dziale II dodano Dział IIa zatytułowany Postępowanie w sprawach gospodarczych. W ten sposób reaktywowano to postępowanie, wprowadzone do K.p.c. od 1 października 1989 r. ustawą z dnia 24 maja 1989 r. o rozpoznawaniu przez sądy spraw gospodarczych (Dz. U. z 1989 r. Nr 33, poz. 175) i zniesione od 3 maja 2012 r. ustawą z dnia 16 września 2011 r. o zmianie ustawy - Kodeks postępowania cywilnego oraz niektórych innych (Dz. U. z 2011 r. Nr 233, poz. 1381). Na ten temat zob. np. M. Muliński, w: Kodeks postępowania cywilnego, t. IB. Komentarz. Art.425-729, red. A. Góra-Błaszczykowska, wyd. 3, Warszawa 2020, s. 58 i nast.

4 Ustawą z dnia 13 lutego 2020 r. o zmianie ustawy - Kodeks postępowania cywilnego oraz niektórych innych ustaw, Dz. U. z 2020 r. poz. 288. Wprowadzenie kolejnego postępowania odrębnego było zbędne. Wystarczające dla podkreślenia specyfiki tego postępowania byłoby określenie sądu wyłącznie właściwego do rozpoznawania tych spraw (Sądu Okręgowego w Warszawie) w art. 17 K.p.c. i ewentualnie odrębne uregulowanie zabezpieczenia roszczeń w tych sprawach.

$5 \quad$ Z Tytułu VII K.p.c. są to: Dział IVc. Postępowanie w sprawach z zakresu regulacji energetyki, Dział IVd. Postępowanie w sprawach z zakresu regulacji telekomunikacji i poczty, Dział IVe. Postępowanie w sprawach z zakresu regulacji transportu kolejowego, Dział IVf. Postępowanie w sprawach z zakresu regulacji rynku wodno-kanalizacyjnego.

6 Na ten temat zob. np. E. Warzocha, Postępowanie administracyjne i sadowe w sprawach emerytalnych w świetle wyników badań aktowych, Warszawa 2009, s. 20-21; A. Góra-Błaszczykowska, O możliwości przekazania spraw $z$ zakresu ubezpieczeń społecznych do wyłacznego rozpoznania sąom administracyjnym - głos w dyskusji, Ubezpieczenia Społeczne. Teoria i Praktyka 2021, nr 2, s. 77-94. 
prezesów odpowiednich urzędów ${ }^{7}$, czemu należałoby poświęcić odrębną wypowiedź, przekraczającą miary prezentowanego artykułu, dlatego w tym miejscu zostaną pominięte szczegółowe uwagi na ich temat.

Mimo że głosy doktryny i praktyki nieczęsto są brane pod uwagę przez legislatorów, podczas kolejnych prac nad Kodeksem postępowania cywilnego warto postulować redukcję liczby postępowań odrębnych, w szczególności tytułowego postępowania w sprawach o ochronę posiadania. Występuje ono w praktyce sądowej stosunkowo rzadko, nie jest właściwie skorelowane z przepisami prawa materialnego, a ponadto budzi spore wątpliwości co do prawidłowości przepisów procesowych, o czym będzie mowa.

Paradoksem jest, że roszczenia wynikające z prawa własności (najszerszego prawa do rzeczy) są dochodzone w trybie zwykłym, a roszczenia dotyczące posiadania (czyli zaledwie władztwa nad rzeczą) - w odrębnym, szybszym postępowaniu. Odrębna regulacja ochrony własności i ochrony posiadania w Kodeksie cywilnym ${ }^{8}$ nie jest obecnie wystarczającym usprawiedliwieniem odmiennego traktowania na gruncie przepisów procesowych, brak ku temu szczególnych wskazań.

Dopuszczalne miary wypowiedzi w czasopiśmie naukowym nie pozwalają na wyczerpującą analizę podjętego tematu, dlatego poniżej zostaną zasygnalizowane tylko najbardziej istotne argumenty, przemawiające za rezygnacją z omawianego postępowania jako odrębnego na gruncie K.p.c. i rozpoznawaniem spraw o ochronę posiadania w postępowaniu zwykłym.

\section{Przyczyny odrębnej regulacji i ogólna konstrukcja ochrony posesoryjnej w K.p.c.}

Przyczyny regulacji postępowań odrębnych są różne, najczęściej wynikają ze specyfiki pewnych spraw cywilnych, wymagających szczególnych unormowań procesowych. W uzasadnieniu uchwały z dnia 29 czerwca 2016 r. ${ }^{9}$ Sąd Najwyższy stwierdził, że wskazane w art. 478 i 479 K.p.c. odrębności usprawiedliwia uregulowana w Kodeksie cywilnym instytucja posiadania oraz przesłanki i metody jej ochrony. Zarówno posesoryjna ochrona własna posiadacza obejmująca obronę konieczną, przywrócenie stanu poprzedniego albo dozwoloną samopomoc, do-

\footnotetext{
Tj. Działy IVc-IVf w Tytule VII K.p.c.
}

8 Ustawa z dnia 23 kwietnia 1964 r. - Kodeks cywilny, tekst jednolity: Dz. U. z 2020 r. poz. 1740 z późn. zm. (dalej: K.c.).

$9 \quad$ III CZP 25/16, OSNC 2017, nr 5, poz. 53. 
puszczalna odpowiednio w chwili naruszania posiadania lub niezwłocznie (natychmiast) po jego naruszeniu, a także ochrona sądowa, o którą może ubiegać się posiadacz w ciągu roku od chwili naruszenia (art. $344 \$ 2$ K.c.), zakładają szybkie działania dotychczasowego posiadacza i sądu. Żądanie przywrócenia naruszonego posiadania nie jest żądaniem skierowanym do prawa, lecz dotyczy stanu faktycznego. Nie zmierza do pozbawienia naruszyciela prawa posiadania rzeczy, lecz do odzyskania przez dotychczasowego posiadacza faktycznego władztwa nad rzeczą w związku z samowolą uprawnionego w realizowaniu przysługującego mu prawa do rzeczy. Wyodrębnienie postępowania w sprawach o naruszenie posiadania służy zapewnieniu szybkiego, choć tymczasowego, rozstrzygnięcia sądu w celu zachowania określonego stanu faktycznego, do czasu uregulowania w sposób zgodny z prawem kwestii spornych, związanych z korzystaniem z rzeczy. Ten cel, poza przepisami prawa materialnego, realizowany jest w procesie przez niedopuszczalność powództwa wzajemnego, przez znacznie ograniczony zakres badania sądu w procesie posesoryjnym do ostatniego stanu posiadania i faktu jego naruszenia, przy jednoczesnym wyłączeniu rozpoznania samego prawa oraz dobrej wiary pozwanego.

Niestety, nie można zgodzić się z argumentem Sądu Najwyższego, iż skoro posiadacz może ubiegać się o ochronę sądową w ciągu roku od chwili naruszenia (art. $344 \$ 2$ K.c.), to należy założyć „szybkie działania dotychczasowego posiadacza i sądu”. Cytowany przepis stanowi: „Roszczenie wygasa, jeżeli nie będzie dochodzone w ciągu roku od chwili naruszenia”. W swej literalnej treści zakłada zatem szybkie działania dotychczasowego posiadacza, a nie sądu. Co więcej, przeprowadzone kilka lat temu badania akt spraw o ochronę posiadania ${ }^{10}$ wykazały długotrwałość postępowań sądowych w sprawach o ochronę posiadania. Moim zdaniem badania te świadczą, że omawiane postępowanie nie spełnia swojej zakładanej, przyspieszonej funkcji przywrócenia do stanu posiadania dotychczasowego posiadacza $^{11}$.

10 Opisane przez M. Warcińskiego w: Ochrona posiadania nieruchomości i służebności gruntowych, Prawo w Działaniu 2013, nr 15, s. 265.

11 Aczkolwiek M. Warciński wysnuł z nich odmienne wnioski. Na s. 265 pisze, że „negatywna ocena dotyczy sposobu dochodzenia do rozstrzygnięć. Krytycznie należy bowiem ocenić przebieg postępowania dowodowego, zbyt długiego, kosztownego, a przede wszystkim zbędnego dla potrzeb procesu posesoryjnego. Uwagi te nie prowadzą jednak do postulatów de lege ferenda. Obecny stan prawa materialnego oraz procesowego jest adekwatny do potrzeb uczestników obrotu. Pozostaje jedynie postulować zmianę pragmatyki sądów w zakresie postępowania posesoryjnego". Z dwoma ostatnimi zdaniami nie można się zgodzić zgodzić, stąd m.in. podjęcie tematu i argumenty za rezygnacją z omawianego postępowania jako odrębnego. 
Analizowane postępowanie miało duże znaczenie w latach 50. ubiegłego stulecia, kiedy brak powszechności ksiąg wieczystych oraz nieformalny obrót nieruchomościami powodował, że tylko ochrona posesoryjna stanowiła jedyną realną formę ochrony nieformalnie, ale realnie istniejącego prawa własności ${ }^{12}$.

Obecne realia są zupełnie inne niż w czasie wprowadzenia Kodeksu postępowania cywilnego (ustanowionego w 1964 r.). Przeciętny podmiot prawa wie o konieczności regulacji stanu prawnego nieruchomości, powszechna jest wiedza na temat ksiąg wieczystych. Ochrona posesoryjna jest często kierowana przeciwko prawom właścicieli, wykorzystywana jest także przez posiadaczy w złej wierze, którzy nie mają żadnego prawa do rzeczy. Przepisy Kodeksu cywilnego nie uzależniają bowiem, o czym będzie jeszcze mowa, możliwości wykorzystania tego postępowania od złej lub dobrej wiary posiadacza.

Tytułowe postępowanie jest uregulowane zaledwie w dwóch przepisach K.p.c. art. 478 i 479. Pierwszy z nich stanowi, że w sprawach o naruszenie posiadania sąd bada jedynie ostatni stan posiadania i fakt jego naruszenia, nie rozpoznając samego prawa ani dobrej wiary pozwanego. Przepis art. 479 K.p.c. wprowadza niedopuszczalność wnoszenia powództwa wzajemnego.

Tak ograniczona kognicja sądu w omawianych sprawach nie ma obecnie racjonalnego uzasadnienia i choćby $\mathrm{z}$ tego powodu omawiane postępowanie powinno zostać wyeliminowane z K.p.c. Wspomniane badania aktowe wykazały ponadto prowadzenie dość długotrwałego i wszechstronnego (a przez to kosztownego) postępowania dowodowego $\mathrm{w}$ analizowanych sprawach, co oznacza ni mniej, ni więcej, że ograniczona formalnie kognicja nie jest w praktyce respektowana, bo sądy prowadzą wyczerpujące postępowania dowodowe. Jakkolwiek ta praktyka nie znajduje uzasadnienia w powołanych wyżej przepisach, to doprowadziła autora badań do konkluzji, że ostatecznie orzeczenia w analizowanych sprawach okazały się trafne ${ }^{13}$. A contrario zatem można postawić być może kontrowersyjną tezę, a raczej pytanie (retoryczne), czy respektowanie w praktyce ograniczonej kognicji mogłoby nie doprowadzać sądów do właściwych, trafnych wniosków, znajdujących odzwierciedlenie w treści wydanych wyroków. Stąd postulat, który rozwiązałby niespójność między praktyką orzeczniczą a regulacją omawianego postępowania, że roszczenia posesoryjne powinny być dochodzone w postępowaniu zwykłym, w którym będzie możliwe (zgodnie z obowiązującymi w nim przepisami) rozpoznanie całokształtu stanu faktycznego i prawnego sprawy.

\footnotetext{
12 A. Laskowska-Hulisz, Zakres orzekania sadu pierwszej instancji w procesie cywilnym, Warszawa 2018, s. $445-446$.

13 M. Warciński, Ochrona posiadania..., s. 265.
} 


\section{Brak właściwej korelacji między prawem materialnym a procesowym w sprawach dotyczących ochrony posiadania}

Zarysowany w poprzednim punkcie rozdźwięk między rodzajem ochrony posiadania i ochrony własności na gruncie K.p.c. wynika, jak się wydaje, z braku właściwej korelacji między prawem procesowym i materialnym. Trafnie postulował T. Wiśniewski $^{14}$, że ustawodawca powinien doprowadzić do symbiozy obszaru materialnoprawnego z procesowym, nie tylko dlatego, że należą one do jednego porządku prawnego. Prawo procesowe nie powinno utrudniać dochodzenia praw na drodze sądowej, czy wręcz zamykać drogi sądowej. Przepis procesowy bowiem, przewidujący ograniczoną kognicję sądu w procesie o ochronę posiadania, nie został w pełni zharmonizowany z rozwiązaniem przyjętym w Kodeksie cywilnym, gdyż zgodnie z regulacją prawnomaterialną od zasady, że skuteczność dochodzenia roszczenia o ochronę posiadania jest niezależna od zgodności posiadania ze stanem prawnym, przewidziano $\mathrm{w}$ art. 344 $\$ 1$ K.c. wyjątek, a mianowicie dopuszczono zarzut, że orzeczeniem sądu lub innego organu państwowego, powołanego do rozpoznawania spraw tego rodzaju, stwierdzono, iż stan posiadania powstały na skutek naruszenia jest zgodny z prawem ${ }^{15}$.

Trafnie konkluduje P. Osowy, że przepis art. 478 K.p.c. nie koreluje z art. 344 $\$ 1$ zdanie 2 K.c., który pozwala na podniesienie w pewnych okolicznościach zarzutu prawa. $\mathrm{Z}$ uwagi na to, że Kodeks postępowania cywilnego i Kodeks cywilny powstawały w tym samym czasie, należy uznać to za przeoczenie prawodawcy i przyjąć, że art. $344 \$ 1$ zdanie 2 K.c. ma zastosowane także do naruszenia posiadania nieruchomości w zakresie służebności gruntowej ${ }^{16}$.

P. Osowy ${ }^{17}$ zauważył też, że w odróżnieniu od procesu petytoryjnego, w którym powód wywodzi swoje roszczenie $\mathrm{z}$ przysługującego mu prawa, istota procesu

14 Kilka refleksji na temat wzajemnych zależności między prawem cywilnym materialnym i procesowym, Polski Proces Cywilny 2020, nr 3, s. 579-599.

15 Podobnie na ten temat wypowiadał się P. Osowy (Roszczenie posesoryjne na przykładzie powództwa o wstrzymanie budowy - spójność uregulowań k.c. i k.p.c. (zagadnienia proceduralne), Rejent 2002, $\mathrm{nr} 4$, s. 87). Jego zdaniem należałoby zmienić formułę, którą posługuje się ustawodawca na gruncie K.p.c. w art. $478-\mathrm{z}$ „naruszenie posiadania” na „ochrona posiadania”. Także D. Ruta (Merytoryczna obrona pozwanego $w$ postępowaniu $w$ sprawach o naruszenie posiadania, Palestra 2012, nr 5-6, s. 58-72), zauważyła, że systemowa wykładnia art. 478 K.p.c. i art. $344 \$ 1$ K.c. każe przyjąć, że rozpoznając sprawę o naruszenie posiadania, sąd nie bada wprawdzie samego prawa ani dobrej wiary pozwanego, ale powinien zbadać, czy naruszenie posiadania, do jakiego doszło, było samowolne oraz czy stan powstały na skutek tego nie został uznany za zgodny z prawem $\mathrm{w}$ prawomocnym orzeczeniu sądu lub innego organu, o którym mowa w art. $344 \$ 1$ K.c.

16 P. Osowy, Powództwo posesoryjne w zakresie ochrony służebności - model ochrony procesowej. Zarys problematyki, Rejent 2005, nr 9, s. 325; M. Warciński, Ochrona posiadania..., s. 257.

17 P. Osowy, Roszczenie posesoryjne..., s. 87. 
posesoryjnego polega na tym, że roszczenie to opiera się wyłącznie na samym posiadaniu, i to niezależnie od tego, czy owo posiadanie odpowiada określonemu prawu, czy też jest posiadaniem bez tytułu prawnego. Przedmiotem ochrony posesoryjnej jest każde posiadanie, zarówno samoistne, jak i zależne. Kumulacja roszczeń w postępowaniu posesoryjnym jest niedopuszczalna. Nie można więc, jak się powszechnie przyjmuje, np. dochodzić roszczenia o ochronę posiadania z roszczeniem o naprawienie szkody lub roszczeniem windykacyjnym. O ile ten drugi zakaz wynika z odmienności trybów (roszczenie windykacyjne należy do trybu zwykłego, zaś roszczenie posesoryjne do trybu odrębnego), o tyle ten pierwszy, w przypadku sytuacji, o której mowa w art. 347 \$ 1 in fine K.c., może budzić uzasadnione wątpliwości ${ }^{18}$.

P. Osowy zwraca uwagę na niepełną harmonizację uregulowań Kodeksu cywilnego i Kodeksu postępowania cywilnego powodującą, iż instytucje materialnoprawne nie mogą znaleźć efektywnego zastosowania ze względu na brak lub nieprzejrzystość norm procesowych. Jego zdaniem powinno się zmienić treść art. 478 K.p.c., biorąc pod uwagę, że w obecnym kształcie przepis ten służy zakazowi kumulacji roszczeń w procesie posesoryjnym; mógłby on mieć następujące brzmienie: „W sprawach o ochronę posiadania nie jest dopuszczalne dochodzenie innych roszczeń”. Przy takim unormowaniu zlikwidowany zostanie stan niepełnego dublowania przesłanek określonych w Kodeksie cywilnym - zakres badania sądu wyznaczony będzie przez samo prawo materialne, a wskazana norma procesowa zyska na elastyczności ${ }^{19}$.

\section{Znaczenie prawne normy art. 478 K.p.c.}

W literaturze przedmiotu pojawiły się wątpliwości co do charakteru prawnego art. 478 K.p.c.: czy jest on zasadą orzekania, czy wyłącznie pełni rolę normy, określającej sposób postępowania w omawianych sprawach.

18 Warto też powołać stanowisko P. Osowego i P. Pełczyńskiego (Sądowa ochrona posiadania - zagadnienia spójności uregulowań kodeksu cywilnego i kodeksu postępowania cywilnego, Przegląd Sądowy 2001, nr 6, s. 17 i nast.), że w K.p.c. ustawodawca skupił się przede wszystkim na uregulowaniu spraw o naruszenie posiadania, expressis verbis nie odnosząc się w ogóle do problematyki roszczeń związanych z zagrożeniem naruszenia posiadania nieruchomości z art. 347 K.c. Głównym przedmiotem regulacji art. 347 K.c. jest stan zagrożenia, a nie naruszenia posiadania.

19 P. Osowy, P. Pełczyński, Sądowa ochrona posiadania..., s. 17-18; P. Osowy, w: Kodeks postępowania cywilnego. Komentarz, red. T. Szanciło, Warszawa 2019, s. 1663-1664. 
W. Siedlecki ${ }^{20}$ dzieli zasady orzekania na trzy grupy: zasady odnoszące się do przedmiotu orzekania, zasady odnoszące się do czasu orzekania (stanu sprawy) oraz zasady dotyczące podstaw orzekania. Ogólna, podstawowa zasada odnosząca się do przedmiotu orzekania ma dać odpowiedź na pytanie, jaki jest stosunek zakresu orzekania sądu do zakresu żądań stron lub uczestników postępowania, z których inicjatywy w zasadzie postępowanie to zostało wszczęte. W ramach tej ogólnej zasady dotyczącej przedmiotu orzekania cytowany autor wywodzi jeszcze zasady szczególne, mające zastosowanie tylko do pewnych kategorii spraw ze względu na ich charakter bądź też do pewnych kwestii, jakie mogą nasunąć się sądowi przy orzekaniu. Do zasad tych zalicza ${ }^{21}$ także badanie ostatniego stanu posiadania i faktu jego naruszenia w sprawach o naruszenie posiadania (art. 478 K.p.c.).

Zdaniem P. Osowego ${ }^{22}$ art. 478 K.p.c. ma charakter szczególnej zasady, dotyczącej przedmiotu orzekania. Przepis ten zdecydowanie zawęża zakres badań sądu i jest przykładem szczególnej dyrektywy interpretacyjnej, nakazującej sądowi orzekającemu w sprawach o naruszenie posiadania stosować regulację szczególną, wynikającą z odrębności tego typu postępowania.

Z tymi poglądami nie można się zgodzić. Brak jest podstaw teoretycznych do nadania art. 478 K.p.c., jako szczególnemu przepisowi, charakteru zasady, w dodatku dotyczącej orzekania. Zasady mają charakter ogólny i nadrzędny, omawiany przepis natomiast jest przepisem szczególnym i ma zastosowanie wyłącznie do spraw o naruszenie posiadania ${ }^{23}$. Wydaje się konieczne przyjęcie, że art. 478 K.p.c. wyznacza tylko zakres postępowania przed sądem w omawianych sprawach. Zakres ten jest bardzo ograniczony, tak samo jak kognicja sądu np. w postępowaniu wieczystoksięgowym. Niestety, ograniczenie kognicji sądu nie jest usprawiedliwione charakterem chronionego dobra, którym jest posiadanie, a więc (zaledwie) faktyczne władztwo nad rzeczą ${ }^{24}$.

20 W. Siedlecki, Zasady orzekania oraz zasady zaskarżania orzeczeń w postępowaniu cywilnym w świetle orzecznictwa Sadu Najwyższego, Warszawa 1982, s. 6-26.

21 Oprócz nich także: zasądzenie odpowiedniej sumy według uznania sądu (art. 322 K.p.c.); ograniczenie odpowiedzialności pozwanego tylko do określonych przedmiotów majątkowych albo do wysokości ich wartości (art. 319 K.p.c.); rozłożenie na raty zasądzonego świadczenia albo wyznaczenie terminu wydania nieruchomości lub opróżnienia pomieszczenia (art. 320 K.p.c.).

22 P. Osowy, Wyrok zasądzający, Warszawa 2020, s. 225.

23 A. Góra-Błaszczykowska, Zasady orzekania, w: System Prawa Procesowego Cywilnego, t. 2, cz. 2. Postępowanie procesowe przed sądem pierwszej instancji, red. T. Wiśniewski, Warszawa 2016, s. 601.

24 W tym miejscu, ze względu na ramy tekstu, pozwalam sobie na pewne uproszczenie, zdając sobie oczywiście sprawę z istnienia bardzo wielu wypowiedzi naukowych na temat pojęcia posiadania i jego (prawidłowej) definicji. Spośród wielu przytoczyć można przykładowo następującą literaturę tego zagadnienia: J. Krajewski, Odrębność postępowania posesoryjnego, Nowe Prawo 1961, nr 2, s. 210; A. Kunicki, Przedmiot i zakres sq̨dowej ochrony posiadania, Państwo i Prawo 1962, z. 8-9, s. 278; tenże, Wyrokowanie 


\section{Kognicja sądu}

Jak wyżej zauważono, kognicja sądu w omawianym postępowaniu jest bardzo ograniczona (przez treść art. 478 K.p.c.), do badania jedynie ostatniego stanu posiadania i faktu jego naruszenia. Ten przepis uniemożliwia zatem rozpoznanie, komu przysługuje prawo do rzeczy oraz dobrej wiary pozwanego, jak i powoda. Powództwo może być bowiem wniesione także przez posiadacza w złej wierze.

Nasuwa się tutaj pewne podobieństwo art. 478 K.p.c. do treści art. $626^{8} \$ 2$ K.p.c., zgodnie z którym rozpoznając wniosek o wpis, sąd bada jedynie treść i formę wniosku, dołączonych do wniosku dokumentów oraz treść księgi wieczystej. Również w postępowaniu wieczystoksięgowym kognicja sądu jest ograniczona, ale z uwagi na (w uproszczeniu) konieczność ochrony najszerszego prawa do rzeczy, jakim jest prawo własności ${ }^{25}$.

Jednakże w przeciwieństwie do założeń i zadań sądu w postępowaniu wieczystoksięgowym, w którym nadaje się przesądzające znaczenie ujawnionemu w księdze wieczystej prawu własności, przepis art. 478 K.p.c. w szczególnych przypadkach będzie zmierzał do zignorowania sensu i znaczenia ksiąg wieczystych i ujawnionego w nich prawa własności, przy jednoczesnej ochronie posiadacza, także w złej wierze, wbrew prawu właściciela. Z tej właśnie przyczyny nie do utrzymania w państwie prawa wydaje się być postępowanie o naruszenie posiadania w obecnym kształcie jako postępowanie odrębne, przyspieszone, w którym nie bada się prawa do rzeczy ani dobrej wiary pozwanego. Tego typu regulacja postępowania, zwłaszcza gdy dotyczy nieruchomości, zaprzecza konstytucyjnie chronionemu prawu własności i wymaga od sądu orzekającego udzielenia ochrony (także) posiadaczom w złej wierze, których szczególne przywileje wynikają z treści 478 i 479 K.p.c. Tylko

w sprawach posesoryjnych, Nowe Prawo 1962, nr 12, s. 1596; tenże, Zmiana powództwa i kumulacja roszczeń w procesie posesoryjnym, Nowe Prawo 1963, nr 6, s. 619; P. Osowy, Reguła przedmiotu orzekania, jako trwała instytucja prawa procesowego cywilnego (wybrane zagadnienia), w: Ars in vita. Ars in iure. Ksiega jubileuszowa dedykowana Profesorowi Januszowi Jankowskiemu, red. A. Barańska, S. Cieślak, Warszawa 2018, s. 119; tenże, Powództwo posesoryjne..., s. 314; W. Siedlecki, Ochrona posesoryjna jednostki w postępowaniu sąowym, Zeszyty Naukowe Uniwersytetu Jagiellońskiego Prace Prawnicze 1983, nr 108, s. 77; K. Przybyłowski, Roszczenie posesoryjne $z$ art. 344 kodeksu cywilnego, Ruch Prawniczy, Ekonomiczny i Socjologiczny 1968, t. 30, z. 3, s. 151; S. Rudnicki, Ponownie o dochodzeniu ochrony spokojnego wspólposiadania w trybie procesu posesoryjnego, Nowe Prawo 1957, nr 10, s. 94.

25 Szczegółowo na temat kognicji sądu wieczystoksięgowego zob. A. Góra-Błaszczykowska, Kognicja sq̨du wieczystoksieggowego, w: Aurea Praxis. Aurea Theoria. Księga pamiątkowa ku czci profesora Tadeusza Erecińskiego, t. 1, red. J. Gudowski, K. Weitz, Warszawa 2011; taż, Kodeks postępowania cywilnego, t. IB. Komentarz. Art. 425-729, red. A. Góra-Błaszczykowska, wyd. 3, Warszawa 2020, s. 754-787; taż, Wszczęcie postępowania wieczystoksięgowego droga elektroniczną, w: Sądowe postępowanie egzekucyjne. Zasadnicze kierunki zmian z 2016 roku, red. A. Marciniak, Sopot 2017, s. 61-76. 
tak bowiem można nazwać brak możliwości merytorycznej obrony pozwanego, skupiając się na fakcie posiadania, bez analizy stanu faktycznego i prawnego sprawy, przy braku możliwości wniesienia powództwa wzajemnego.

W literaturze prawa cywilnego podkreśla się $e^{26}$, że proces posesoryjny ma na celu ustalenie przez sąd, czy posiadanie, które jest przedmiotem sporu, należy lub należało do powoda oraz czy pozwany samowolnie naruszył posiadanie. Postępowanie posesoryjne powinno być wolne, w czystej postaci, od wszelkich zarzutów dotyczących samego prawa będącego podstawą posiadania. Taka koncepcja zakresu kognicji sądu w tym postępowaniu odrębnym jest zgodna z zasadą prawa materialnego, że ochrona posesoryjna przysługuje, zgodnie z art. $344 \$ 1$ K.c., posiadaczowi i to niezależnie od tego, czy jest on w dobrej, czy złej wierze oraz czy posiadanie jest zgodne z prawem, czy bezprawne.

W wyroku z dnia 17 grudnia 2003 r. ${ }^{27}$ Sąd Najwyższy uznał, że żądanie przywrócenia naruszonego posiadania nie jest żądaniem skierowanym do prawa, lecz dotyczy stanu faktycznego. Nie zmierza do pozbawienia naruszyciela prawa posiadania rzeczy, lecz do odzyskania przez dotychczasowego posiadacza faktycznego władztwa nad rzeczą w związku z samowolą uprawnionego w realizowaniu przysługującego mu prawa do rzeczy (art. 478 K.p.c.). Sąd Najwyższy wyjaśnił też znaczenie przepisu art. $344 \$ 1$ zdanie 2 K.c., który nie przewiduje powództwa o ustalenie, że stan posiadania powstały na skutek naruszenia posiadania jest zgodny z prawem, ani nie wyraża interesu prawnego strony pozwanej. Przepis ten dopuszcza możność powołania się strony pozwanej na prawomocne orzeczenie, z którego wynika, że przysługuje jej prawo, którego realizacji służy pozbawienie lub naruszenie posiadania dotychczasowego posiadacza. Przewiduje więc jedynie interes faktyczny, wyrażający się wygraniem procesu posesoryjnego, a nie interes prawny, wyrażający się wszakże określoną sytuacją materialnoprawną. Uprawnienie do naruszenia lub pozbawienia dotychczasowego posiadacza jego posiadania, związane $\mathrm{z}$ wykazanym $\mathrm{w}$ innym postępowaniu prawem do rzeczy naruszającego posiadanie, unicestwia $\mathrm{w}$ procesie o ochronę posesoryjną skutki samowoli naruszyciela. Wykazaniu prawa, z którym uprawnienie to jest związane, służy m.in. orzeczenie nakazujące dotychczasowemu posiadaczowi wydanie rzeczy (art. $222 \$ 1$ K.c.). Roszczenie windykacyjne przysługuje właścicielowi także wówczas, gdy odzyskał on faktyczne władztwo nad rzeczą, ale nie wiąże się to $\mathrm{z}$ wyzbyciem się przez

\footnotetext{
26 Tak np. J. Gołaczyński, w: System Prawa Prywatnego, t. 4. Prawo rzeczowe, red. E. Gniewek, wyd. 4, Warszawa 2021, s. 673 i nast.

27 IV CK 297/02, LEX nr 558334.
} 
dotychczasowego posiadacza woli władania rzeczą, czego dowodem jest powództwo o ochronę posiadania.

Wydaje się jednak, że zacytowane wyżej, trafne na gruncie Kodeksu cywilnego poglądy nie usprawiedliwiają zasadności wprowadzenia szczególnej ochrony posiadania także na gruncie przepisów procesowych. Wystarczająca wydaje się być ochrona udzielona posiadaczom przez przepisy prawa materialnego. $\mathrm{W}$ procesie cywilnym natomiast ochrona posiadania nie powinna być uprzywilejowana względem ochrony własności.

\section{Problem badania dobrej wiary}

Kolejnym problemem, pojawiającym się w postępowaniu w sprawach dotyczących posiadania, jest problem dobrej wiary, łączący się zresztą z poprzednimi uwagami. Z przepisu art. $344 \$ 1$ K.c. wynika, że roszczenie posesoryjne nie jest zależne od dobrej wiary posiadacza ani od zgodności posiadania ze stanem prawnym. Sąd bada więc jedynie ostatni stan posiadania oraz fakt jego naruszenia, nie mogąc badać przysługującego pozwanemu prawa do władania rzeczą. Oczywiście powód z własnej inicjatywy może dowodzić także w procesie posesoryjnym, że przysługuje mu do rzeczy prawo, o ile jednak pomoże to sądowi w ustaleniu, że był (jest) posiadaczem rzeczy i że jego posiadanie zostało naruszone.

Wątpliwości budzi to, czy dobra wiara może być przedmiotem rozstrzygania $\mathrm{w}$ tym postępowaniu. W sytuacji gdy przepis art. 5 K.c. dotyczy nadużycia prawa, trudno przyjąć, że wystąpienie z roszczeniem o ochronę posiadania może być nadużyciem prawa. Niemniej możliwość taką przyjmuje Sąd Najwyższy i niektórzy przedstawiciele doktryny ${ }^{28}$.

Moim zdaniem, skoro ustawodawca dopuścił możliwość występowania o ochronę posesoryjną także przez posiadacza w złej wierze, korzystanie przez niego z tego uprawnienia samo przez się nie może być traktowane jako nadużycie prawa. Jednakże w omawianych sprawach pojawia się inna wątpliwość, czy w ogóle dopuszczalne jest $\mathrm{w}$ procesie posesoryjnym podnoszenie zarzutu $\mathrm{z}$ art. 5 K.c., a jeśli tak, to

28 Tak np. J. Grzybowski, Prawo rzeczowe, Warszawa 1989, s. 226; J. Ignatowicz, Ochrona posiadania, Warszawa 1963, s. 148; tenże, w: Kodeks cywilny. Komentarz, t. 1, red. Z. Resich, Warszawa 1972, s. 799; K. Przybyłowski, Roszczenia posesoryjne..., s. 154. Por. też orzeczenie SN z dnia 5 maja 1953 r., I C 252/53 (Państwo i Prawo 1953, z. 11, s. 730) oraz orzeczenie SN z dnia 6 kwietnia 1963 r., III CR 117/62 (Państwo i Prawo 1964, z. 4, s. 703) z glosami: S. Grzybowskiego oraz A. Ohanowicza (Państwo i Prawo 1964, z. 7, s. 170 i nast.). 
czy jego rozpoznanie nie stanowi rozszerzenia zakresu kognicji sądu, określonego bardzo wąsko w art. 478 K.p.c.

M. Warciński ${ }^{29}$ uznaje, że nie ma powodu, by odmówić zastosowania w tym postępowaniu art. 5 K.c., zawierającego generalny zakaz nadużywania każdego prawa (uprawnienia) podmiotowego, także roszczenia posesoryjnego. Kwestią wykładni jest wskazanie kryteriów, według których ocena roszczenia posesoryjnego z punktu widzenia art. 5 K.c. doprowadzi do uznania, że jest ono nadużyte. Sąd Najwyższy ${ }^{30}$ dopowiada, że powództwo o naruszenie posiadania powinno ulec oddaleniu tylko w razie rażącej kolizji roszczenia z zasadami współżycia społecznego ${ }^{31}$.

Zdaniem K. Przybyłowskiego ${ }^{32}$ w sprawach o naruszenie posiadania sąd nie może ograniczyć się do badań ,jedynie ostatniego stanu posiadania i faktu jego naruszenia”, jednakże jeśli już wspomina się o dobrej wierze, należałoby raczej ogólnie wyłączyć rozważanie dobrej wiary (czyjejkolwiek, a nie tylko pozwanego). Z tym poglądem trudno się obecnie zgodzić, niemniej wątpliwość zostałaby rozwiana poprzez rezygnację $\mathrm{z}$ odrębnego postępowania $\mathrm{w}$ omawianych sprawach i rozpoznawanie ich w postępowaniu zwykłym. Można wówczas, w zależności od okoliczności, rozważać i stosować również art. 5 K.c., co byłoby uzasadnione zwłaszcza wówczas, gdy o ochronę posesoryjną wystąpiłby posiadacz w złej wierze albo gdy pozwany byłby w dobrej wierze.

Obserwacja praktyki sądowej wskazuje, że wyłączenie możliwości rozważania dobrej wiary stron, a nie tylko pozwanego, może prowadzić do wydania orzeczenia zgodnego z prawem, lecz sprzecznego z zasadami współżycia społecznego, gdyż często przed sądami o ochronę posesoryjną występują posiadacze (najczęściej nieruchomości) w złej wierze, zajmujący je bez podstawy prawnej, pozwanymi zaś są właściciele. Tego rodzaju sytuacja jest obecnie trudna do zaakceptowania z punktu widzenia konstytucyjnej ochrony prawa własności.

Jedynie na marginesie należy w tym miejscu wspomnieć, że Sąd Najwyższy uznaje, iż dozwolone jest badanie prawa powoda w sytuacji, gdyby mogło to pomóc w ustaleniu faktu posiadania ${ }^{33}$. J. Ignatowicz zauważa, że potrzeba taka może

29 M. Warciński, Ochrona posiadania..., s. 254.

$30 \quad$ Wyrok SN z dnia 6 maja 1974 r., III CRN 79/74, LEX nr 7486; uchwała SN z dnia 7 grudnia 1970 r., III CZP 75/70, OSNCP 1971, nr 7-8, poz. 127.

31 W tym miejscu warto przywoływać pogląd A. Kunickiego (w: System Prawa Cywilnego, t. 2. Prawo własności i inne prawa rzeczowe, red. J. Ignatowicz, 1977, s. 883), według którego niedopuszczalność zarzutu wadliwości posiadania wynika właśnie z art. 342 K.c., który zakazuje samowolnego naruszenia posiadania. Zakaz ten dotyczy również posiadacza, który utracił posiadanie przez samowolę posiadacza aktualnego.

32 K. Przybyłowski, Roszczenie posesoryjne..., s. 157-158.

33 Zob. wyroki SN z dnia 3 czerwca 1966 r., III CR 108/66, OSP 1967, z. 10, poz. 234 z glosą A. Kunickiego. 
zaistnieć w przypadku współposiadania oraz posiadania wynikającego ze służebności $^{34}$. Odmiennie twierdzi H. Ciepła ${ }^{35}$, uznając, że zakaz badania przez sąd zgodności posiadania z prawem odnosi się zarówno do powoda, jak i do pozwanego.

Z przepisu art. $344 \$ 1$ K.c. wynika kolejny problem natury procesowej, ponieważ roszczenie posesoryjne traci swoją skuteczność, gdy „prawomocne orzeczenie sądu lub innego powołanego do rozpatrywania spraw tego rodzaju organu państwowego stwierdziło, że stan posiadania powstały na skutek naruszenia jest zgodny z prawem". Interpretacja tego przepisu także budzi wątpliwości, czy chodzi tylko o orzeczenie, które zostało wydane po fakcie naruszenia, czy także orzeczenie wydane przed naruszeniem. Przeważa zapatrywanie, że chodzi tu jedynie o takie orzeczenie wydane po naruszeniu posiadania ${ }^{36}$. Według A. Kunickiego przyjęcie odmiennego stanowiska prowadziłoby do niepożądanej i sprzecznej z ochroną posesoryjną dopuszczalności samowolnego naruszenia posiadania z powołaniem się na tytuł wykonawczy bez jego wykonywania w drodze egzekucji ${ }^{37}$.

J. Gołaczyński ${ }^{38}$ zauważa, że skutki prawne związane z orzeczeniem, o którym mowa w art. $344 \$ 1$ K.c., mogą być istotne dla procesu posesoryjnego tylko wtedy, gdy będzie to prawomocny wyrok wydany w procesie petytoryjnym. Wyrok wydany w procesie petytoryjnym i zaopatrzony jedynie w rygor natychmiastowej wykonalności nie ma takiego skutku, ponieważ możliwa jest jeszcze jego zmiana lub uchylenie. Ponadto przepis art. $344 \$ 1$ K.c. wyraźnie wskazuje, że orzeczenie musi być prawomocne $e^{39}$.

34 Tak J. Ignatowicz, w: Kodeks cywilny. Komentarz, t. 1, s. 796-797.

35 Tak H. Ciepła, w: Kodeks Postępowania cywilnego, t. 3. Komentarz. Art. 425-729, red. A. Marciniak, Warszawa 2020, s. 253.

36 Więcej A. Kunicki, w: System Prawa Cywilnego, t. 2, s. 882; tenże, Exceptio iuris w procesie posesoryjnym, Ruch Prawniczy, Ekonomiczny i Socjologiczny 1974, t. 36, z. 3, s. 127; J. Ignatowicz, w: Kodeks cywilny. Komentarz, t. 1, s. 797. Zob. uchwała SN z dnia 26 lipca 1968 r., III CZP 52/68, OSNCP 1969, nr 3, poz. 48 z glosą B. Hofmańskiego, Nowe Prawo 1970, nr 5, s. 166.

37 A. Kunicki, w: System Prawa Cywilnego, t. 2, s. 869.

38 J. Gołaczyński, System Prawa Prywatnego, t. 4, s. 676.

39 Ostatecznie cytowany autor wymienia takie orzeczenia jak: nakazujące świadczenie związane z własnością, ustalające prawo, postanowienie znoszące współwłasność. Natomiast orzeczeniami takimi nie są wyroki sądów polubownych, ugody sądowe i pozasądowe, ugody zawarte w postępowaniu pojednawczym, mimo że mogą one stanowić tytuł wykonawczy. Prawomocnym orzeczeniem innego organu powołanego do rozpoznawania spraw tego rodzaju organu państwowego jest np. decyzja o scalaniu gruntów. Chodzi tu zatem o decyzję organu państwowego, który ma kompetencję do ustalania prawa własności lub innego prawa do przedmiotu ochrony posesoryjnej, zob. uchwała SN z dnia 21 listopada 1980 r., III CZP 43/80, OSNCP 1981, nr 8, poz. 142. 


\section{Legitymacja czynna i bierna}

Legitymacja czynna przysługuje posiadaczowi samoistnemu, jak i zależnemu (art. 336 K.c.), zarówno posiadaczowi w dobrej, jak i w złej wierze. Legitymowany biernie jest podmiot, który dopuścił się naruszenia posiadania, a także podmiot, na którego korzyść naruszenie nastąpiło. Roszczenie posesoryjne jest uprawnieniem względnym, skierowanym zawsze tylko wobec konkretnych podmiotów; może być skierowane wobec każdego, kto narusza posiadanie lub z tego naruszenia korzysta ${ }^{40}$.

Kolejnym problemem, wygenerowanym li tylko przez odrębne uregulowanie postępowania o naruszenie posiadania, jest problem możliwości zastosowania w nim art. 192 pkt 3 K.p.c. Przepis ten stanowi, że zbycie w toku sprawy rzeczy lub prawa objętych sporem nie ma wpływu na dalszy bieg sprawy, nabywca może jednak wejść na miejsce zbywcy za zezwoleniem strony przeciwnej.

Odnosząc się do legitymacji biernej w sprawie o naruszenie posiadania, Sąd Najwyższy ${ }^{41}$ przyjął, że powództwo o przywrócenie posiadania rzeczy nie może być skutecznie dochodzone przeciwko osobie, która naruszyła posiadanie rzeczy, jeżeli w toku sprawy przeniosła posiadanie tej rzeczy na inną osobę. W uzasadnieniu Sąd podkreślił, że żądanie przywrócenia naruszonego posiadania nie jest żądaniem skierowanym do prawa, lecz dotyczy stanu faktycznego. Nie zmierza do pozbawienia naruszyciela prawa posiadania rzeczy, ale do odzyskania przez dotychczasowego posiadacza faktycznego władztwa nad rzeczą w związku z samowolą uprawnionego $\mathrm{w}$ realizowaniu przysługującego mu prawa do rzeczy. Wyodrębnienie postępowania w sprawach o naruszenie posiadania służy zapewnieniu szybkiego, choć tymczasowego rozstrzygnięcia sądu w celu zachowania określonego stanu faktycznego, do czasu uregulowania w sposób zgodny z prawem kwestii spornych, związanych z korzystaniem z rzeczy. Ten cel, poza przepisami prawa materialnego, realizowany jest w procesie przez niedopuszczalność powództwa wzajemnego, przez znacznie ograniczony zakres badania sądu w procesie posesoryjnym do ostatniego stanu posiadania i faktu jego naruszenia, przy jednoczesnym wyłączeniu rozpoznania samego prawa oraz dobrej wiary pozwanego. Cechą charakterystyczną roszczenia posesoryjnego jest to, że może być ono skutecznie dochodzone tylko o tyle, o ile naruszyciel ma tę rzecz w swoim ręku. Z chwilą więc, gdy osoba, która pozbawiła posiadacza władztwa nad rzeczą, sama to władztwo utraciła, przestaje być legitymowana biernie, a wytoczone przeciw niej żądanie staje się bezprzedmiotowe. Tym

\footnotetext{
40 J. Ignatowicz, Ochrona posiadania, s. 136; na ten temat również M. Warciński, Ochrona posiadania..., s. 249.

41 W uchwale z dnia 29 czerwca 2016 r., III CZP 25/16, OSNP 2017, nr 5, poz. 53.
} 
wyraża się sens ochrony posiadania z punktu widzenia jej skuteczności ${ }^{42}$. W związ$\mathrm{ku} \mathrm{z}$ tym przeniesienie przez pozwanego, który samowolnie naruszył posiadanie powoda, posiadania nieruchomości, której dotyczy spór, na osobę trzecią, dokonane po dacie zawisłości sporu, skutkuje według Sądu Najwyższego, utratą legitymacji biernej w sprawie o przywrócenie naruszonego posiadania.

Z poglądem tym nie zgadza się M. Manowska ${ }^{43}$, podnosząc, że przesłanki, jakie podlegają badaniu w tym postępowaniu, nie powinny decydować o zastosowaniu procesowej normy art. 192 pkt 3 K.p.c. Trafnie zauważył P. Telenga ${ }^{44}$, że skutkiem przyjęcia poglądu wyrażonego w cytowanym orzeczeniu Sądu Najwyższego jest możliwość wielokrotnego przenoszenia posiadania w toku procesu, celem uniemożliwienia wydania orzeczenia co do meritum sprawy. Skoro bowiem zdaniem Sądu Najwyższego przeniesienie posiadania w trakcie procesu powoduje konieczność umorzenia postępowania i wytoczenia powództwa przeciwko nowemu posiadaczowi, taka sytuacja (przeniesienie posiadania) może powtórzyć się kilka razy, uniemożliwiając merytoryczne rozstrzygnięcie sprawy. In concreto umożliwiałoby to matactwo procesowe oraz przewlekało proces, a także unicestwiałoby sens ochrony posesoryjnej.

Szczegółowe uwagi, zawarte w cytowanej już wypowiedzi P. Telengi, warte są $\mathrm{w}$ tym miejscu szerszego przytoczenia. Otóż po analizie historycznej autor ten konkluduje, że zastosowanie art. 192 pkt 3 K.p.c. w procesie posesoryjnym stanowi logiczną i oczywistą konsekwencję sukcesywnej i alternatywnej w swej istocie legitymacji procesowej (ad causam, rzeczowej), wynikającej z art. $344 \$ 1$ zdanie 1 K.c. Przy tym założeniu autor stawia tezę, że jest to przykład legitymacji zbiorowej (grupowej), która przysługuje zarówno przeciwko osobie, która jako pierwsza naruszyła posiadanie, jak i jej dalszym następcom ${ }^{45}$.

K. Stefaniuk jest zdania, że wyrok przywracający posiadanie, wydany w stosunku do pozwanego będzie skuteczny i wykonalny, aczkolwiek nie w stosunku do pozwanego, który nie władając już rzeczą, nie może jej wydać, ale przeciwko osobie, na którą pozwany przeniósł posiadanie, którego uprzednio został przezeń pozbawiony powód. Z mocy art. 192 pkt 3 K.p.c., in principio, wyrok ten ma rozszerzoną prawomocność materialną, rozciągającą się na osobę, która uzyskała od pozwanego posiadanie rzeczy będącej przedmiotem sporu i na którą przeszedł obowiązek

\footnotetext{
42 Tak też Sąd Najwyższy w wyroku z dnia 7 lipca 1995 r., I CRN 52/95, LEX nr 82284.

43 M. Manowska, w: Kodeks postępowania cywilnego. Komentarz, t. 2. Art. 478-1217, red. M. Manowska, wyd. 4, Warszawa 2021, s. 32.

44 P. Telenga, O wpływie przeniesienia posiadania w trakcie procesu posesoryjnego na legitymacje procesowa pozwanego, Polski Proces Cywilny 2018, nr 3, s. 326.

45

Tamże, s. 328.
} 
wydania tej rzeczy. Powód, który na podstawie art. 192 pkt 3 K.p.c. uzyskał wyrok przeciwko pozwanemu nakazujący wydanie nieruchomości (przywracający posiadanie), skuteczny wobec osoby, na którą $\mathrm{w}$ toku procesu zostało przeniesione władanie nieruchomością, może na mocy art. $791 \$ 1$ K.p.c. otrzymać tytuł wykonawczy przeciwko temu pozwanemu i następnie prowadzić na podstawie tego tytułu egzekucję przeciwko osobie władającej tą nieruchomością, bez nadawania przeciw niej klauzuli wykonalności ${ }^{46}$. Takie samo stanowisko prezentuje G. Wolak ${ }^{47}$, dopuszczając stosowanie $w$ procesie posesoryjnym normy z art. 192 pkt 3 K.p.c., w wyniku czego nie dochodzi ani do naruszenia odrębności tego postępowania, ani do wydania wyroku, który nie byłby skuteczny wobec osoby, na którą pozwany przeniósł posiadanie, a więc byłby niewykonalny.

Podsumowując tę część wypowiedzi, należy stwierdzić, że postępowanie o ochronę posiadania, ze względu na ograniczoną kognicję sądu i brak korelacji z istotnymi przepisami K.p.c., jak omówiony art. 192 pkt 3 K.p.c., może być przedłużane i blokowane czynnościami faktycznymi przeniesienia posiadania. Zarysowany problem co do skutków przeniesienia posiadania dla toku postępowania o jego naruszenie jest kolejnym argumentem za przekazaniem omawianych spraw do postępowania zwykłego. Dzięki temu sąd mógłby stosować art. 192 pkt 3 K.p.c., jak również zresztą art. 5 K.c. i inne, budzące wątpliwości co do zastosowania w omawianym postępowaniu.

\section{Orzekanie w sprawach o przywrócenie posiadania}

Orzeczenia sądu o przywróceniu posiadania zależą od rodzaju naruszenia. Jeżeli posiadacz został pozbawiony posiadania, sąd nakaże wydanie utraconej rzeczy. Jeżeli doszło do zakłócenia posiadania, sąd zakaże dokonywania czynów zakłócających posiadanie (zakaże dalszych naruszeń). W sentencji orzeczenia sąd powinien wyraźnie określić świadczenie, do którego zobowiązuje pozwanego. Nie jest wykonalne orzeczenie, którego sentencja zawiera tylko nakazanie pozwanemu, aby „przywrócił naruszone posiadanie powoda”. Konieczne jest określenie przez sąd za-

46 K. Stefaniuk, Przeniesienie przez pozwanego uzyskanego samowolnie posiadania na inna osobę $w$ toku procesu posesoryjnego - skutki materialne i procesowe. Glosa do uchwały Sądu Najwyższego z 29.06.2016, III CZP 25/16, Przegląd Sądowy 2018, nr 2, s. 97-98.

47 G. Wolak, Glosa do uchwały Sądu Najwyższego z 29.06.2016, III CZP 25/16. Dochodzenie przywrócenia naruszonego posiadania, $w$ sytuacji gdy $w$ toku procesu posesoryjnego doszło do przeniesienia posiadania, Rejent 2020, nr 7, s. 107. 
kresu obowiązków pozwanego, tj. wydanie rzeczy albo powstrzymanie się od dalszego naruszania (zakłócania) posiadania.

Sąd nie może jednak przywrócić posiadania rzeczy, która przestała istnieć48; do przywrócenia posiadania konieczne jest istnienie przedmiotu posiadania $\mathrm{w}$ chwili wyrokowania $^{49}$. J. Ignatowicz podkreśla także, że jeżeli osoba utraciła władztwo nad rzeczą, wydanie rzeczy przez tę osobę jest niemożliwe. Wówczas można skierować do tej osoby jedynie roszczenie o odszkodowanie, natomiast roszczenie o wydanie rzeczy powinno być skierowane przeciwko temu, kto uzyskał władztwo nad rzeczą ${ }^{50}$.

Jak już zasygnalizowano, w omawianych sprawach może zostać zastosowany art. 5 K.c., jako podstawa oddalenia powództwa. Możliwość taką dopuścił Sąd Najwyższy w uchwale składu 7 Sędziów z dnia 23 listopada 1959 r. ${ }^{51}$, podkreślając, iż może tak być w sytuacji, gdy powód występuje przeciwko samowoli pozwanego, która była reakcją na samowolę powoda, jeśli okazałoby się - przy uwzględnieniu całokształtu okoliczności konkretnego przypadku - że żądanie powoda przywrócenia mu posiadania godzi w zasady współżycia społecznego. Również w takim wyjątkowym przypadku nie można by mówić o pojawieniu się na nowo roszczenia pierwotnego posiadacza o ochronę posiadania. Roszczenie to bowiem (w każdym razie jego zasadnicza część) zostało skonsumowane przez wejście pierwotnego posiadacza $\mathrm{z}$ powrotem, chociaż samowolnie, $\mathrm{w}$ posiadanie przedmiotu sporu ${ }^{52}$. Tak więc istnieje możliwość oddalenia powództwa na podstawie art. 5 K.c., jeśli okazałoby się przy uwzględnieniu całokształtu okoliczności konkretnego przypadku - że żądanie powoda przywrócenia mu posiadania godzi w zasady współżycia społecznego ${ }^{53}$.

\section{Zakończenie}

Postępowanie o naruszenie posiadania (jako odrębne), nieskorelowane właściwie z przepisami prawa materialnego, ograniczone do badania tylko faktu naruszenia posiadania, powinno zostać wyeliminowane z Kodeksu postępowania cywilnego.

\footnotetext{
48 Tak S. Breyer, Ochrona własności. Posiadanie, Katowice 1965-1966, s. 83; J. Ignatowicz, Kodeks cywilny. Komentarz, t. 1, s. 793.

49 A. Kunicki, Przedmiot i zakres..., s. 287.

50 J. Ignatowicz, Ochrona posiadania, s. 137.

511 CO 21/59, OSNCK 1960, nr 3, poz. 65.

52 Zob. też J. Ignatowicz, Ochrona posiadania, s. 129.

53 Pogląd ten został powołany także w uzasadnieniu uchwały SN z dnia 7 maja 1976 r., III CZP 26/76, OSNCP 1976, nr 11, poz. 240.
} 
Spory dotyczące posiadania, tak jak ma to miejsce w sprawach dotyczących własności (w szczególności nieruchomości), powinny toczyć się w postępowaniu zwykłym, w którym możliwe jest wykorzystanie wszystkich środków dowodowych, dopuszczalnych według K.p.c., celem wyjaśnienia spornych okoliczności, istotnych dla rozstrzygnięcia sprawy i uwzględnianie wszelkich, dopuszczonych przez K.p.c. zarzutów.

Z obserwacji praktyki sądowej, w szczególności orzecznictwa Sądu Najwyższego, wynika, że omawiane postępowanie nieustannie budzi poważne wątpliwości, mimo że zostało wprowadzone do K.p.c. kilkadziesiąt lat temu. W szczególności trudno obecnie zaakceptować fakt, że art. 478 K.p.c. jest wykorzystywany do ochrony nieruchomości posiadanej bez podstawy prawnej. Właściciel, pozbawiony władztwa, nie ma żadnych szybkich sposobów ponownego wejścia w posiadanie, gdyż posiadacz (zazwyczaj były najemca, któremu wypowiedziano umowę najmu lub którego umowa wygasła albo osoba zajmująca lokal bez jakiejkolwiek podstawy prawnej) nie tylko nie zwalnia lokalu dobrowolnie, najczęściej nie ponosząc za niego żadnych opłat, wykorzystując środki przewidziane prawem do ochrony posiadania (w złej wierze). Gdy weźmie się pod uwagę ten przykład, widoczna staje się zbędność dalszego istnienia postępowania o naruszenie posiadania jako odrębnego trybu procesu.

Jak już zaznaczono, założenia ustawodawcy, który wprowadził omawiane postępowanie w realiach lat 50. i 60. ubiegłego wieku, były takie, aby z uwagi na ograniczoną dostępność do ksiąg wieczystych czy innych form rejestrowania własności umożliwić uzgodnienie nieformalnego prawa $\mathrm{z}$ faktycznym posiadaniem. Chroniono $\mathrm{w}$ ten sposób posiadacza, któremu przysługiwało nieformalne prawo do rzeczy. Obecnie takie sytuacje są w praktyce bardzo rzadkie z uwagi na powszechność ksiąg wieczystych i wiedzy na temat prawidłowego sposobu przenoszenia własności. Dlatego postępowanie o naruszenie posiadania jako odrębne, przyspieszone i uniemożliwiające badanie tytułu prawnego do rzeczy oraz dobrej wiary, nie powinno się ostać dłużej w K.p.c.

Niniejszy tekst, ze względu na ograniczone rozmiary, ma na celu jedynie wskazanie przykładowych problemów prawnych, z którymi musi mierzyć się sąd rozpoznający sprawę o naruszenie posiadania. Brak korelacji z prawem materialnym, brak możliwości pełnego, kompleksowego rozpoznania sprawy czyni to postępowanie długotrwałym, unaocznia nieadekwatność jego odrębnej (od zwykłego postępowania) regulacji.

Tylko przekazanie spraw o naruszenie posiadania do postępowania zwykłego, umożliwiającego rozpoznanie wszystkich zarzutów, zmian podmiotowych, pozwoli na wydanie trafnego rozstrzygnięcia, zgodnego z prawem materialnym i zasadami 
współżycia społecznego. Dlatego warto byłoby, aby ustawodawca zrezygnował z dalszego odrębnego uregulowania omawianego postępowania, gdyż wywołuje ono więcej problemów, niż potencjalnych zysków.

\section{Bibliografia}

Breyer S., Ochrona własności. Posiadanie, Katowice 1965-1966.

Ciepła H., Kodeks postępowania cywilnego, t. 3. Komentarz. Art. 425-729, red. A. Marciniak, Warszawa 2020.

Czachórski W., Skutki posiadania i jego ochrona wedtug obowiązującego prawa cywilnego, Nowe Prawo 1957, z. 6.

Gołaczyński J., w: System Prawa Prywatnego, t. 4. Prawo rzeczowe, red. E. Gniewek, wyd. 4, Warszawa 2021.

Góra-Błaszczykowska A., w: Kodeks postępowania cywilnego, t. IB. Komentarz. Art. 425-729, red. A. Góra-Błaszczykowska, wyd. 3, Warszawa 2020.

Góra-Błaszczykowska A., Kognicja sądu wieczystoksięgowego, w: Aurea Praxis. Aurea Theoria. Ksiega pamiątkowa ku czci profesora Tadeusza Erecińskiego, t. 1, red. J. Gudowski, K. Weitz, Warszawa 2011.

Góra-Błaszczykowska A., O możliwości przekazania spraw z zakresu ubezpieczeń społecznych do wyłacznego rozpoznania sądom administracyjnym - głos $w$ dyskusji, Ubezpieczenia Społeczne. Teoria i Praktyka 2021, nr 2.

Góra-Błaszczykowska A., Wszczęcie postępowania wieczystoksięgowego droga elektroniczna, w: Sądowe postępowanie egzekucyjne. Zasadnicze kierunki zmian z 2016 roku, red. A. Marciniak, Sopot 2017.

Góra-Błaszczykowska A., Zasady orzekania, w: System Prawa Procesowego Cywilnego, t. 2, cz. 2. Postępowanie procesowe przed sądem pierwszej instancji, red. T. Wiśniewski, Warszawa 2016.

Grzybowski S., Glosa do orzeczenia SN z 6.4.1963 r., III CR 117/62, Państwo i Prawo 1964, z. 7.

Grzybowski S., Prawo cywilne. Zarys prawa rzeczowego, Warszawa 1976.

Hofmański B., Glosa do uchwały SN z 26.7.1968 r., III CZP 52/68, Nowe Prawo 1970, nr 5.

Ignatowicz J., Ochrona posiadania, Warszawa 1963.

Ignatowicz J., w: Kodeks cywilny. Komentarz, t. 1, red. Z. Resich, Warszawa 1972.

Krajewski J., Odrębność postępowania posesoryjnego, Nowe Prawo 1961, nr 2.

Kunicki A., Exceptio iuris w procesie posesoryjnym, Ruch Prawniczy, Ekonomiczny i Socjologiczny 1974, t. 36, z. 3.

Kunicki A., Glosa do wyroku SN z 3.6.1966 r., III CR 108/66, OSP 1967, z. 10, poz. 234.

Kunicki A., Przedmiot i zakres sądowej ochrony posiadania, Państwo i Prawo 1962, z. 8-9.

Kunicki A., w: System Prawa Cywilnego, t. 2. Prawo własności i inne prawa rzeczowe, red. J. Ignatowicz, Wrocław 1977.

Kunicki A., Wyrokowanie w sprawach posesoryjnych, Nowe Prawo 1962, nr 12. 
Kunicki A., Zmiana powództwa i kumulacja roszczeń w procesie posesoryjnym, Nowe Prawo 1963, nr 6.

Kunicki I., w: Broniewicz W., Marciniak A., Kunicki I., Postępowanie cywilne w zarysie, Warszawa 2016.

Laskowska-Hulisz A., Zakres orzekania sądu pierwszej instancji w procesie cywilnym, Warszawa 2018.

Manowska M., w: Kodeks postępowania cywilnego. Komentarz, t. 2. Art.478-1217, red. M. Manowska, wyd. 4, Warszawa 2021.

Muliński M., w: Kodeks postępowania cywilnego, t. IB. Komentarz. Art. 425-729, red. A. GóraBłaszczykowska, wyd. 3, Warszawa 2020.

Ohanowicz A., Glosa do orzeczenia SN z 6.4.1963 r., III CR 117/62, Państwo i Prawo 1964, z. 7 .

Osowy P., Powództwo posesoryjne w zakresie ochrony służebności - model ochrony procesowej. Zarys problematyki, Rejent 2005, nr 9.

Osowy P., Reguła przedmiotu orzekania, jako trwała instytucja prawa procesowego cywilnego (wybrane zagadnienia), w: Ars in vita. Ars in iure. Ksiegga jubileuszowa dedykowana Profesorowi Januszowi Jankowskiemu, red. A. Barańska, S. Cieślak, Warszawa 2018.

Osowy P., Roszczenie posesoryjne na przykładzie powództwa o wstrzymanie budowy - spójność uregulowań k.c. i k.p.c. (zagadnienia proceduralne), Rejent 2002, nr 4.

Osowy P., w: Kodeks postępowania cywilnego. Komentarz, red. T. Szanciło, Warszawa 2019.

Osowy P., Wyrok zasadzający, Warszawa 2020.

Osowy P., Pełczyński P., Sądowa ochrona posiadania - zagadnienia spójności uregulowań kodeksu cywilnego i kodeksu postępowania cywilnego, Przegląd Sądowy 2001, nr 6.

Siedlecki W., Ochrona posesoryjna jednostki w postępowaniu sądowym, Zeszyty Naukowe Uniwersytetu Jagiellońskiego Prace Prawnicze 1983, nr 108.

Siedlecki W., Zasady orzekania oraz zasady zaskarżania orzeczeń w postępowaniu cywilnym w świetle orzecznictwa Sadu Najwyższego, Warszawa 1982.

Przybyłowski K., Roszczenie posesoryjne $z$ art. 344 kodeksu cywilnego, Ruch Prawniczy, Ekonomiczny i Socjologiczny 1968, t. 30, z. 3.

Romańska M., Zbycie rzeczy lub prawa objętych sporem (art. 192 pkt 3 k.p.c.) w orzecznictwie sądowym, w: Aurea Praxis. Aurea Theoria. Księga pamiątkowa ku czci profesora Tadeusza Erecińskiego, t. 1, red. J. Gudowski, K. Weitz, Warszawa 2011.

Rudnicki S., Ponownie o dochodzeniu ochrony spokojnego współposiadania $w$ trybie procesu posesoryjnego, Nowe Prawo 1957, nr 10.

Ruta D., Merytoryczna obrona pozwanego w postępowaniu w sprawach o naruszenie posiadania, Palestra 2012, nr 5-6.

Stefaniuk K., Przeniesienie przez pozwanego uzyskanego samowolnie posiadania na inna osobe $w$ toku procesu posesoryjnego - skutki materialne i procesowe. Glosa do uchwaty Sadu Najwyższego z 29.06.2016, III CZP 25/16, Przegląd Sądowy 2018, nr 2.

Telenga P., O wpływie przeniesienia posiadania w trakcie procesu posesoryjnego na legitymacje procesowa pozwanego, Polski Proces Cywilny 2018, nr 3.

Wiśniewski T., Kilka refleksji na temat wzajemnych zależności między prawem cywilnym materialnym i procesowym, Polski Proces Cywilny 2020, nr 3.

Warciński M., Ochrona posiadania nieruchomości i służebności gruntowych, Prawo w Działaniu 2013, nr 15. 
Warzocha E., Postępowanie administracyjne i sądowe $w$ sprawach emerytalnych $-w$ świetle wyników badań aktowych, Warszawa 2009.

Wolak G., Glosa do uchwały Sądu Najwyższego z 29.06.2016, III CZP 25/16. Dochodzenie przywrócenia naruszonego posiadania, $w$ sytuacji gdy $w$ toku procesu posesoryjnego doszło do przeniesienia posiadania, Rejent 2020, nr 7. 
